\title{
新型四硫富瓦烯-三苯胺类光敏染料理论研究
}

\author{
翁小龙 ${ }^{1}$ 王 艳 $^{1}$ 贾春阳 ${ }^{1, *}$ 万中全 ${ }^{1} \quad$ 陈喜明 $^{2} \quad$ 姚小军 $^{3}$ \\ ( ${ }^{1}$ 电子科技大学微电子与固体电子学院, 电子薄膜与集成器件国家重点实验室, 国家电磁辐射控制材料工程技术 \\ 研究中心，成都 610054; 2 中车株洲电力机车研究所有限公司，湖南 株洲 412001; \\ 3 兰州大学化学化工学院, 功能有机分子化学国家重点实验室, 兰州 730000)
}

\begin{abstract}
摘要: 在简单结构的 D- $\pi-A$ 三苯胺光敏染料(YD1)中引入不同数量的四硫富瓦烯(TTF)单元作为次级电子给体 以增强有机光敏染料的给电子能力, 设计了两个结构分别为 D-D- $\pi-A(Y D 2)$ 以及 2D-D- $\pi-A(Y D 3)$ 的光敏染料 分子, 并且采用密度泛函理论(DFT)和含时密度泛函理论(TD-DFT)分别模拟计算了纯光敏剂分子及其吸附二 氧化钛团簇后的几何构型、电子结构以及光物理性能。采用周期性密度泛函理论模拟计算光敏染料分子在二 氧化钛(101)面吸附的表面形貌以及态密度(DOS)。计算结果表明, TTF 单元的引入不仅可以有效减少光敏染 料分子的团聚, 还可以提升其吸收性能。此外, 光吸收效率 $(\mathrm{LHE})$ 、电子注入驱动力 $\left(\Delta G^{\text {inject }}\right)$ 以及 $D O S$ 的计 算结果显示, YD2 和YD3 理论上可以呈现出比YD1更高的短路电流密度 $\left(J_{\mathrm{sc}}\right)$ 以及开路电压 $\left(V_{\mathrm{oc}}\right)$ 。因此, 通过 本文的理论研究表明, TTF 单元可以作为有机光敏染料中的次级电子给体来改善光敏染料的性能。
\end{abstract}

关键词: 三苯胺; 四硫富瓦烯; 光敏染料; 密度泛函理论; 染料敏化太阳能电池 中图分类号: 0641

\section{Theoretical Investigation of Novel Tetrathiafulvalene- Triphenylamine Sensitizers}

\author{
WENG Xiao-Long ${ }^{1} \quad$ WANG Yan ${ }^{1} \quad$ JIA Chun-Yang ${ }^{1, *} \quad$ WAN Zhong-Quan \\ CHEN Xi-Ming ${ }^{2} \quad$ YAO Xiao-Jun ${ }^{3}$
}

('State Key Laboratory of Electronic Thin Films and Integrated Devices, National Engineering Research Center of Electromagnetic Radiation Control Materials, School of Microelectronics and Solid-State Electronics, University of Electronic Science and Technology of China, Chengdu 610054, P. R. China; ${ }^{2}$ CSR Zhuzhou Electric Locomotive Research Institute Co. Ltd., Zhuzhou 412001, Hunan Province, P. R. China; ${ }^{3}$ State Key Laboratory of Applied Organic Chemistry, School of Chemistry and Chemical Engineering, Lanzhou University, Lanzhou 730000, P. R. China)

\begin{abstract}
Two novel sensitizers with D-D- $\pi-A$ (YD2) and 2D-D- $\pi-A$ (YD3) structures were designed by introducing different numbers of tetrathiafulvalene (TTF) unit as the auxiliary electron donor based on the simple $\mathrm{D}-\pi$-A triphenylamine sensitizer (YD1) to enhance the electron donating ability. The geometries, electronic structures, and optical properties of $\mathrm{YD} 1-3$ before and after binding to $\mathrm{TiO}_{2}$ clusters were investigated. Owing to introduction of TTF unit, YD2 and YD3 show larger steric hindrance and a narrower band gap than YD1. Moreover, the estimated light-harvesting efficiency (LHE), injection driving force $\left(\Delta G^{\text {inject }}\right)$ values, and density of states (DOS) calculations indicate that YD2 and YD3 should show higher short-circuit photocurrent density $\left(J_{\mathrm{sc}}\right)$ and open-circuit photovoltage $\left(V_{\mathrm{oc}}\right)$ than YD1 with the presence of TTF unit. All of the results indicate that TTF unit can be used as an auxiliary electron donor in organic sensitizers to improve their photovoltaic properties.
\end{abstract}

Key Words: Triphenylamine; Tetrathiafulvalene; Sensitizer; Density functional theory;

Received: February 1, 2016; Revised: May 3, 2016; Published on Web: May 3, 2016.

*Corresponding author. Email: cyjia@uestc.edu.cn; Tel: +86-28-83201991; Fax: +86-28-83202569.

The project was supported by the National Natural Science Foundation of China, (21572030, 21272033, 21402023).

国家自然科学基金(21572030, 21272033, 21402023)资助项目

(C) Editorial office of Acta Physico-Chimica Sinica 
Dye-sensitized solar cell

\section{Introduction}

Dye-sensitized solar cells (DSSCs), which can convert light into electricity, have received increasing attention owing to their advantages as environmentally benign, easy preparation, and low cost $^{1}$. There are four components in DSSCs: sensitizer, electrolyte, counter electrode, photo-anode. Among them, dye sensitizer attracts much attention for its special role, capture the light energy. The best efficient sensitizer which is based on porphyrin sensitizers, has reached an overall solar energy conversion efficiency $(\eta)$ of $13 \%$ under standard AM $1.5 \mathrm{G}$ sunlight ${ }^{2}$. And the efficiencies of the star sensitizers (N3, N719, and black dyes) which are all based on ruthenium sensitizers have exceeded $12 \%$ as well ${ }^{3}$. With the characteristics of high molar extinction coefficients, tunable absorption and electrchemical properties by suitable molecular design, metal-free sensitizers have been extensively investigated. Recently, Wang and coworkers ${ }^{4}$ synthesized a new pure organic sensitizer with the $\eta$ of $12.5 \%$, which could be equal to the ruthenium sensitizers and the porphyrin sensitizers. At present, kinds of metal-free dyes as sensitizers have been developed and shown good performances, such as: triphenylamine dyes ${ }^{5}$, carbazole dyes $^{6}$, fluorene dyes ${ }^{7,8}$, coumarin dyes ${ }^{9}$, and indoline dyes ${ }^{10,11}$.

Triphenylamine (TPA) based dyes possess much attention because of their non-planar structures, prominent electrondonating abilities, and their hole-transporting properties ${ }^{12,13}$. In 2010, Wang and coworkers ${ }^{14}$ synthesized a novel triphenylamine based organic dyes with the $\eta$ of $10.3 \%$. Most of them present good power conversion efficiencies in DSSCs ${ }^{15}$. However, the electron-donating ability of simple TPA unit is not strong and the absorption range is not enough broad. In order to enhance the power conversion efficiency, researchers pay attention to the modification of the structure of TPA-based dyes, mainly by introducing different kinds of auxiliary electron-donor units. Carbazole $^{16}$, imidazole ${ }^{17}$, and phenothiazine moieties ${ }^{18}$ are the most common auxiliary electron-donor units. Recently, Tarsang and coworkers $^{19}$ modified the simple TPA dyes by introducing different numbers of auxiliary donor groups into triphenylamine core and investigated them by theoretical computation. The calculation results show that compared with the D- $\pi$-A and D-D- $\pi$-A systems, $2 \mathrm{D}-\mathrm{D}-\pi$-A system shows the most red-shift of absorption wavelength.

Tetrathiafulvalene (TTF) and its derivatives have been employed first to design conducting materials such as organic metals, semiconductors, and superconductors ${ }^{20}$. After that, TTFs as electron donors paired with suitable acceptors have been well exploited in controlled self-assembled nanostructures, environmentally responsive devices, nonlinear optical arrays, as well as light harvesting complexes ${ }^{21}$. TTF and its derivatives with their characteristic of strong reversible electron donating abilities could be used as the electron donor in sensitizers for DSSCs ${ }^{22,23}$. In 2010, Grätzel and coworkers ${ }^{24}$ reported successful photovoltaic conversion with a new class of stable tetrathiafulvalene derivatives and the $\eta$ of dye PAB-3 based cell reached 3.8\%. Later, Liu et al. ${ }^{25}$ prepared a new TTF-based sensitizer in which TTF acts as the electron donor and the $\eta$ of related cell has achieved $6.47 \%$. However, few of TTF units have been used as the auxiliary electron donor in sensitizers until now.

In this work, to enhance the electron donating ability, the simple TPA sensitizer (YD1) is modified by introducing different number of TTF units as the auxiliary electron donor to form two novel sensitizers with D-D- $\pi$-A (YD2) and 2D-D- $\pi$-A (YD3) structures, theoretical investigation on the electronic structures and optical properties of the two metal-free sensitizers are performed. The structures of YD1-3 are shown in Fig.1.

\section{Theoretical approach}

\subsection{Method}

Density functional theory (DFT) and time-dependent DFT (TDDFT) are the reliable theoretical computation tools to forecast the structures and properties which mainly contain the valence excitation energies and absorption spectra of the organic dyes ${ }^{26,27}$. The modeling of $\left(\mathrm{TiO}_{2}\right)_{9}$ cluster has been proved that it is enough to reproduce adequately the electronic absorption spectra of dye-<smiles>N#C/C(=C/c1ccc(N(c2ccccc2)c2ccccc2)cc1)C(=O)O</smiles>

YD1

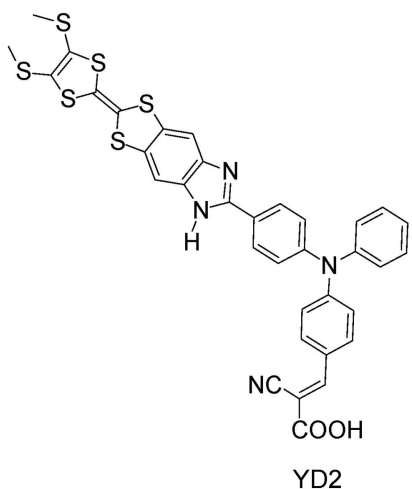

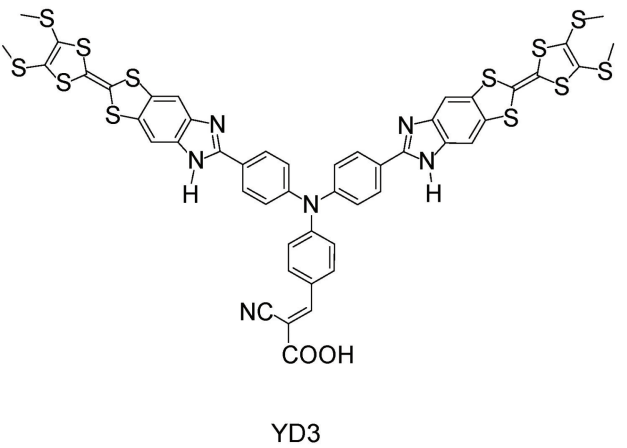

Fig.1 Molecular structures of YD1 - 3 
$\mathrm{TiO}_{2}$ systems by Sanchez-de-Armas and his group ${ }^{28,29}$. The groundstate geometries and frequency calculations of YD1 -3 before and after binding to $\left(\mathrm{TiO}_{2}\right)_{9}$ clusters in vacuum are both first optimized by using $\mathrm{B}^{2} \mathrm{LYP}^{30,31}$ hybrid functional alone with $6-31 \mathrm{G}^{*}$ for $\mathrm{C}, \mathrm{H}$, $\mathrm{O}, \mathrm{N}, \mathrm{S}$ atoms, effective core potential (ECP) LANL2DZ, and its accompanying basis set for Ti atom. The optimized geometries are true minima for there is no imaginary frequency. We select coulomb-attenuating method CAM-B3LYP functional ${ }^{32}$ to calculate the vertical excitation energies and the oscillator strengths ${ }^{33}$ within the framework of TD-DFT. And five solvents are chosen to predict the effects of solvent on the absorption spectra by using non-equilibtium implemention of the conductor-like polarizable continuum model $(\mathrm{CPCM})^{34,35}$. All calculations were performed with Gaussian $09^{36}$.

In addition, the adsorption of sensitizers on the $\mathrm{TiO}_{2}$ surface was further investigated. The starting geometry for $\left(\mathrm{TiO}_{2}\right)_{38}$ was discussed in a previous literature ${ }^{37}$, the adsorption of sensitizers on the $\left(\mathrm{TiO}_{2}\right)_{38}$ cluster was performed with DFT calculation by $\mathrm{DMol}^{3}$ program in Materials Studio version 5.5. All the electronic calculations were made with DNP basis sets, whose size is comparable to Gaussian $6-31 G^{* *}$, but DNP is more accurate than a Gaussian basis set of the same size ${ }^{38}$. The exchange-correlation interaction was treated within the generalized gradient approximation (GGA) with the functional parameterized by Perdew, Burke, and Ernzerhof (PBE) $)^{39}$. We used DFT Semi-core Pseudo potentials (DSPPs) to treat the core electron ${ }^{40}$. After optimization, the adsorption energies $\left(E_{\text {ads }}\right)$ of sensitizers on the $\left(\mathrm{TiO}_{2}\right)_{38}$ clusters were obtained by using the following equation:

$$
E_{\text {ads }}=E_{\text {dye }}+E_{\mathrm{TiO}_{2}}-E_{\text {dye }+\mathrm{TiO}_{2}}
$$

where $E_{\mathrm{dye}}$ is the total energy of isolated dye, $E_{\mathrm{TiO}_{2}}$ is the total energy of $\left(\mathrm{TiO}_{2}\right)_{38}$, cluster and $E_{\mathrm{dye}+\mathrm{TiO}_{2}}$ is the total energy of dye$\left(\mathrm{TiO}_{2}\right)_{38}$ complexes. After applying the above expression equation, the results of the positive value of $E_{\text {ads }}$ indicate a stable adsorption.

\subsection{Theoretical background}

The overall conversion efficiency ( $\eta)$, which is related to the shortcircuit photocurrent density $\left(J_{\mathrm{sc}}\right)$, open-circuit photovoltage $\left(V_{\mathrm{oc}}\right)$, and fill factor (FF), is an important parameter to characterize the performance of DSSCs. In general, $\eta$ can be expressed as follows:

$$
\begin{aligned}
& \eta=\mathrm{FF} J_{\mathrm{sc}} V_{\mathrm{oc}} / I_{\mathrm{s}} \\
& \mathrm{FF}=J_{\max } V_{\max } / J_{\mathrm{sc}} V_{\mathrm{oc}}
\end{aligned}
$$

The $J_{\mathrm{sc}}$ is the photocurrent per unit area $\left(\mathrm{mA} \cdot \mathrm{cm}^{-2}\right)$ when the applied bias potential is zero. When no current is flowing through the cell, the potential equals the $V_{\text {oc. }}$ The FF is defined as the maximum power output $\left(J_{\max } V_{\max }\right)$ divided by the product of $J_{\mathrm{sc}}$ and $V_{\mathrm{oc}}$ (Eq.(1)). $I_{\mathrm{s}}$ is the intensity of the incident light. From the above equations, the most effective way of increasing $\eta$ is to improve the $J_{\text {sc }}$ and $V_{\text {oc }}$. The $J_{\text {sc }}$ depends on the light harvesting efficiency at a given wavelength $(\operatorname{LHE}(\lambda))$, charge collection efficiency ( $\left.\eta_{\text {collect }}\right)$, and electron injection efficiency $\left(\Phi_{\text {inject }}\right)$ :

$$
\begin{aligned}
& J_{\text {sc }}=\int \operatorname{LHE}(\lambda) \Phi_{\text {inject }} \eta_{\text {collect }} \mathrm{d} \lambda \\
& \mathrm{LHE}=1-10^{-f}
\end{aligned}
$$

$f$ is the oscillator strength of the dye associate to the maximum absorption wavelength $\left(\lambda_{\max }\right)$ in the equation. There is a linear correlation between $f$ and $\mathrm{LHE}^{41}$, the larger $f$ the higher LHE. In addition, a larger $\Phi_{\text {inject }}$ which is related to the injection driving force $\left(\Delta G^{\text {inject }}\right)$ could also gain a high $J_{\text {sc. The }} \Delta G^{\text {inject }}$ can be calculated as follows ${ }^{42}$,

$$
\Delta G^{\text {inject }}=E^{\text {dye**}}-E_{\text {СB }}
$$$$
E^{\text {dye* }}=E^{\text {dye }}-E_{0-0}
$$

where $E^{\text {dye* }}$ is the oxidation potential energy of the dye in the excited state and $E_{\mathrm{CB}}$ is the reduction potential of the conduction band of $\mathrm{TiO}_{2}$. In this work, $E_{\mathrm{CB}}$ is $-4.0 \mathrm{eV}$ for $\mathrm{TiO}_{2}{ }^{43}$. $E^{\text {dye }}$ is the oxidation potential energy of the dye in the ground state, while $E_{0-0}$ is an electronic vertical transition energy corresponding to the $\lambda_{\max }$.

The $V_{\text {oc }}$ can be expressed as follows ${ }^{44}$,

$$
V_{\text {oc }}=E_{\mathrm{CB}} / q+k T \ln \left(n_{\mathrm{c}} / N_{\mathrm{CB}}\right) / q-E_{\text {redox }} / q
$$

where $q$ is the unit charge, $n_{\mathrm{c}}$ is the number of electrons in the conduction band, $k T$ is the thermal energy, $N_{\mathrm{CB}}$ is the accessible density of conduction band states, and $E_{\text {redox }}$ is the reduction-oxidation potential of the electrolyte, $E_{\mathrm{CB}}$ is the conduction band edge of semiconductor.

\section{Results and discussion}

\subsection{Ground state optimized geometries}

The ground state geometries of YD1 -3 before and after binding to $\left(\mathrm{TiO}_{2}\right)_{9}$ clusters in vacuum are shown in Fig.2. The corresponding data are summarized in Table 1.

The ground state geometries demonstrate that the three benzene rings in the triphenylamine cores of YD1-3 are all non-planar, the non-planar geometries could prevent the intermolecular $\pi-\pi$ stacked aggregation ${ }^{45}$. TTF unit is considered as a strong auxiliary electron donor linking on the triphenylamine core to increase the electron donor ability of the sensitizer. It is found that when one TTF unit is introduced into the triphenylamine core (YD2), the inter- ring torsion angles (IDA) R1-R2 and R1-R3 increase to $28.36^{\circ}$ and $29.27^{\circ}\left(25.98^{\circ}\right.$ and $26.28^{\circ}$ for YD1), which is helpful to prevent $\pi-\pi$ stacked aggregation efficiently. In order to further extend the electron donor ability and enhance the light absorption, another TTF is introduced into YD2, the IDA R1-R2 and R1-R3 of YD3 further increase to $31.62^{\circ}$ and $31.41^{\circ}$, suggesting that YD3 has a larger steric hindrance compared to YD2. Besides, the steric hindrance of the tail of TTF moiety as antenna could also prevent unfavorable aggregation of the sensitizers on the $\mathrm{TiO}_{2}$ surface and the charge recombination at the $\mathrm{TiO}_{2}$ /electrolyte interface, both of which have an adverse effect on the photocurrent and photovoltage and therefore contribute to increase the $\eta$ of DSSCs. The dihedral angles between auxiliary donor and primary donor were named as external dihedral angle (EDA). The smaller EDAs could provide the smooth electron delocalization in the $\pi$-conjugated bridge resulting in an extended $\pi$-conjugated system. The calculated EDAs for YD2 $\left(6.48^{\circ}\right)$ and YD3 $\left(2.17^{\circ}\right.$ and $\left.1.24^{\circ}\right)$ suggest that both of the two sensitizers have good extent of electron delocalization.

Moreover, intramolecular charge transfer (ICT) transition is another factor which can affect the overall solar energy conversion efficiency. The extent of ICT transition is related to the conjugation degree between the donor and the acceptor. As shown in 


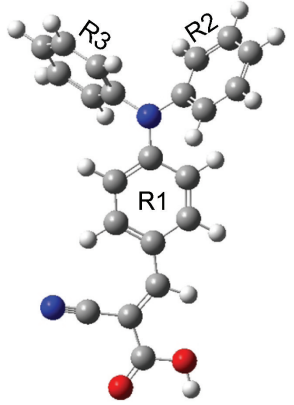

YD1

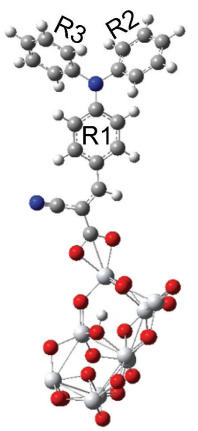

$\mathrm{YD} 1-\left(\mathrm{TiO}_{2}\right)_{9}$

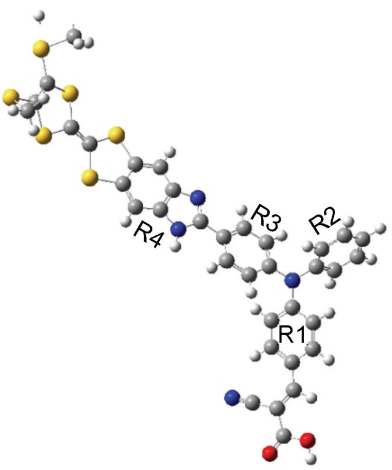

YD2

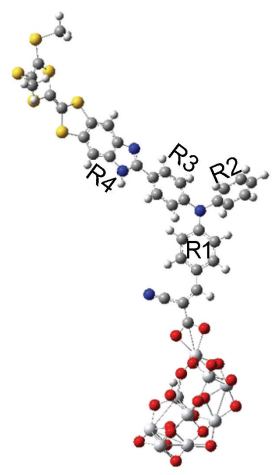

$\mathrm{YD} 2-\left(\mathrm{TiO}_{2}\right)_{9}$

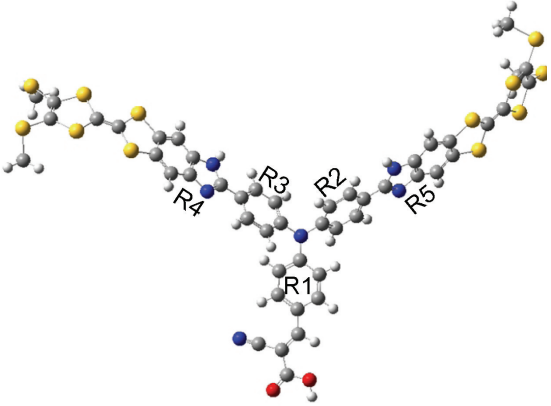

YD3

Fig.2 Optimized geometries of $\mathrm{YD1}-3$ before and after binding to $\left(\mathrm{TiO}_{2}\right)_{9}$ clusters

Table 1 Selected dihedral angles $(\Phi)$ of YD1 -3 by B3LYP/6-31G*

\begin{tabular}{cccccc}
\hline \multirow{2}{*}{ Dye } & \multicolumn{5}{c}{$\Phi /\left(^{\circ}\right)$} \\
\cline { 2 - 6 } & R1-R2 & R1-R3 & R3-R4 & R2-R5 & R1-A \\
\hline YD1 & 25.98 & 26.28 & - & - & 0.38 \\
YD2 & 28.36 & 29.27 & 6.48 & - & 2.82 \\
YD3 & 31.62 & 31.41 & 2.17 & 1.24 & 0.45 \\
\hline \multicolumn{7}{c}{ A: acceptor }
\end{tabular}

Table 1, the dihedral angles between phenylene (R1) and acceptor in free sensitizers $\mathrm{YD} 1, \mathrm{YD} 2$, and $\mathrm{YD} 3$ are $0.38^{\circ}, 2.82^{\circ}$, and $0.45^{\circ}$, respectively, expressing strong conjugation degree between donor and acceptor, indicating that the excited electron could transfer from the electron donor to the electron acceptor successfully.

\subsection{Electronic structures and molecular orbital energy levels}

The energy levels and frontier molecular orbital distributions of YD1 -3 before and after binding to $\left(\mathrm{TiO}_{2}\right)_{9}$ clusters are shown in Fig.S1 (in Supporting Information) and Fig.3. The electron distributions of YD2 and YD3 at HOMOs are mainly delocalized on the TTF units while the electron distribution of YD1 at HOMO is delocalized on the whole molecular. The LUMOs of YD1 -3 are mainly delocalized on the spacers and acceptor units. This indicates that YD2 and YD3 present a better electron-separated state between HOMO and LUMO than YD1.

The charge transfer orientation is associated with energy levels of the HOMO of the donor and the LUMO of the acceptor, which is an important factor that affects the electron injection efficien$\mathrm{cy}^{46}$. Fig. $\mathrm{S} 1$ shows that the LUMOs of the three sensitizers are all above and close to the conduction band $(\mathrm{CB})$ of $\mathrm{TiO}_{2}(-4.0 \mathrm{eV})$ and the HOMOs of the sensitizers are all located under the redox potential of $\mathrm{I}^{-} / \mathrm{I}_{3}^{-}(-4.8 \mathrm{eV})$ electrolyte, suggesting that the excited electrons of YD2 and YD3 could inject into $\mathrm{TiO}_{2}$ efficiently and the oxidation state of them could get electrons from the redox couple of $\mathrm{I}^{-} / \mathrm{I}_{3}^{-}$electrolyte to regenerate. So, on the energy level match, the two sensitizers are appropriate as dye sensitizers for DSSCs. Besides, we can see that for free sensitizers YD2 and YD3, the calculated energy gaps are 2.55 and $2.52 \mathrm{eV}$, respectively, suggesting that a decrease of 0.58 and $0.61 \mathrm{eV}$ compared with YD1 $(3.13 \mathrm{eV})$, which should be ascribe to the introducing of TTF unit. The narrowed band gaps are helpful for excited electron from HOMO to LUMO and broaden the absorption spectrum.

When the sensitizers bind to the $\left(\mathrm{TiO}_{2}\right)_{9}$ clusters, the LUMO energy decreases sharply while the HOMO energy changes slightly. The electrons transfer from cyanoacrylic acid electron acceptor (free sensitizers) to the $\left(\mathrm{TiO}_{2}\right)_{9}$ cluster (sensitizers- $\left(\mathrm{TiO}_{2}\right)_{9}$ complex), leading to the fact that the electron distributions in sensitizers- $\left(\mathrm{TiO}_{2}\right)_{9}$ at LUMO were delocalized at $\left(\mathrm{TiO}_{2}\right)_{9}$ clusters. It is the main reason why the LUMO of YD1- $\left(\mathrm{TiO}_{2}\right)_{9}$, YD2-( $\left.\mathrm{TiO}_{2}\right)_{9}$, and $\mathrm{YD} 3-\left(\mathrm{TiO}_{2}\right)_{9}$ decrease sharply and it implies that $\mathrm{TiO}_{2}$ cluster has stronger electron-withdrawing ability than the cyanoacrylic $\operatorname{acid}^{47}$. 


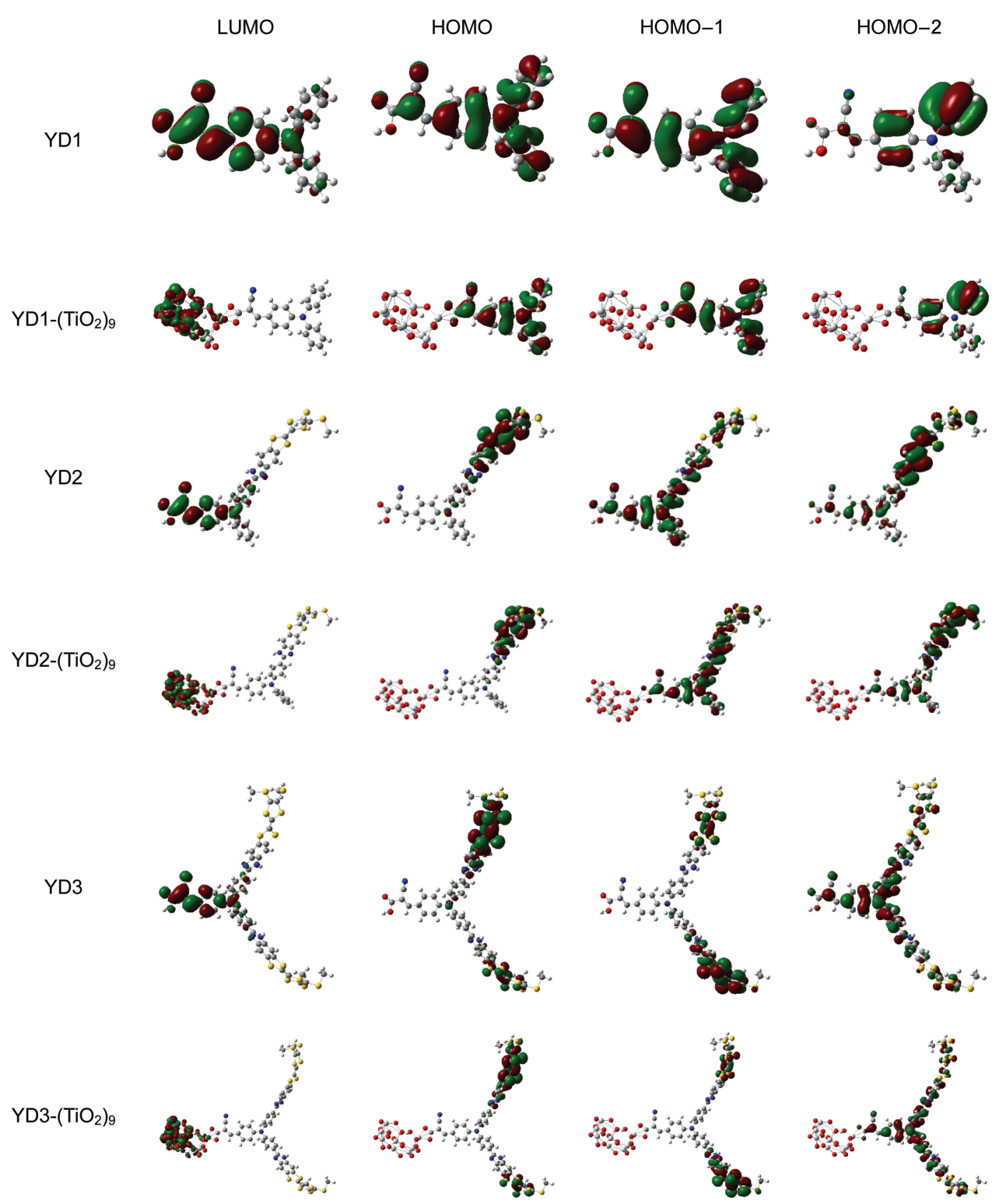

Fig.3 Frontier molecular orbital distributions of YD1 -3 before and after binding to $\left(\mathrm{TiO}_{2}\right)_{9}$ cluster

\subsection{Electronic absorption spectra}

Solvent effects have been considered as an important factor in $\operatorname{DSSCs}^{48,49}$. Diffirent sensitized solvents for the dyes would considerably affect photovoltaic property of DSSC $^{50}$. The absorption wavelengths, oscillator strengths, and transition energies of YD13 before and after binding to the $\left(\mathrm{TiO}_{2}\right)_{9}$, clusters are calculated in vacuum and in five solvents $\left(\mathrm{EtOH}, \mathrm{CH}_{2} \mathrm{Cl}_{2}, \mathrm{CHCl}_{3}, \mathrm{CCl}_{4}\right.$, and dimethylformamide (DMF)) through TD-CAM-B3LYP with CPCM calculations. The calculation results of the three sensitizers in vacuum are summarized in Table $\mathrm{S} 1$, the absorption spectra properties of $\mathrm{YD} 1-3$ before and after binding to $\left(\mathrm{TiO}_{2}\right)_{9}$ clusters are shown in Fig.4 and Fig.5.

For the simulated absorption spectra in vacuum, compared with YD1, a red-shift of absorption (14 nm) and broader absorption band are found for YD2. Besides, the number of the absorption peaks increases from one to two and the absorption strength also increases intensively. An even more intensive absorption strength and red-shift of absorption are observed when two TTF units are introduced into the triphenylamine core (YD3). Table S1 exhibits the absorption wavelengths, electron transition energies, oscillator strengths, and molecular orbitals assignment of YD1-3. In our opinion, the new absorption peak around $346 \mathrm{~nm}$ of YD3 is resulted by the red-shift of the absorption peak $319 \mathrm{~nm}$ of YD2, which may be $\pi-\pi^{*}$ transitions when the TTF units are introduced. Similarly, the absorption band at $370-450 \mathrm{~nm}$ is assigned to the ICT transition. A further investigation of YD1 -3 indicates that the absorption peak of YD1 around $363 \mathrm{~nm}$ is assigned to the ICT transition from $\mathrm{H} \rightarrow \mathrm{L}(+93 \%)$, the relevant peak for YD2 around $377 \mathrm{~nm}$ is mostly due to the ICT transition from $\mathrm{H}-1 \rightarrow \mathrm{L}$ $(+65 \%)$, and YD3 around $378 \mathrm{~nm}$ mainly occur from $\mathrm{H}-2 \rightarrow \mathrm{L}$ $(+57 \%)$ transition. The ICTs of YD2 and YD3 don't mainly occur from HOMO to LUMO orbital, which is mainly caused by the 

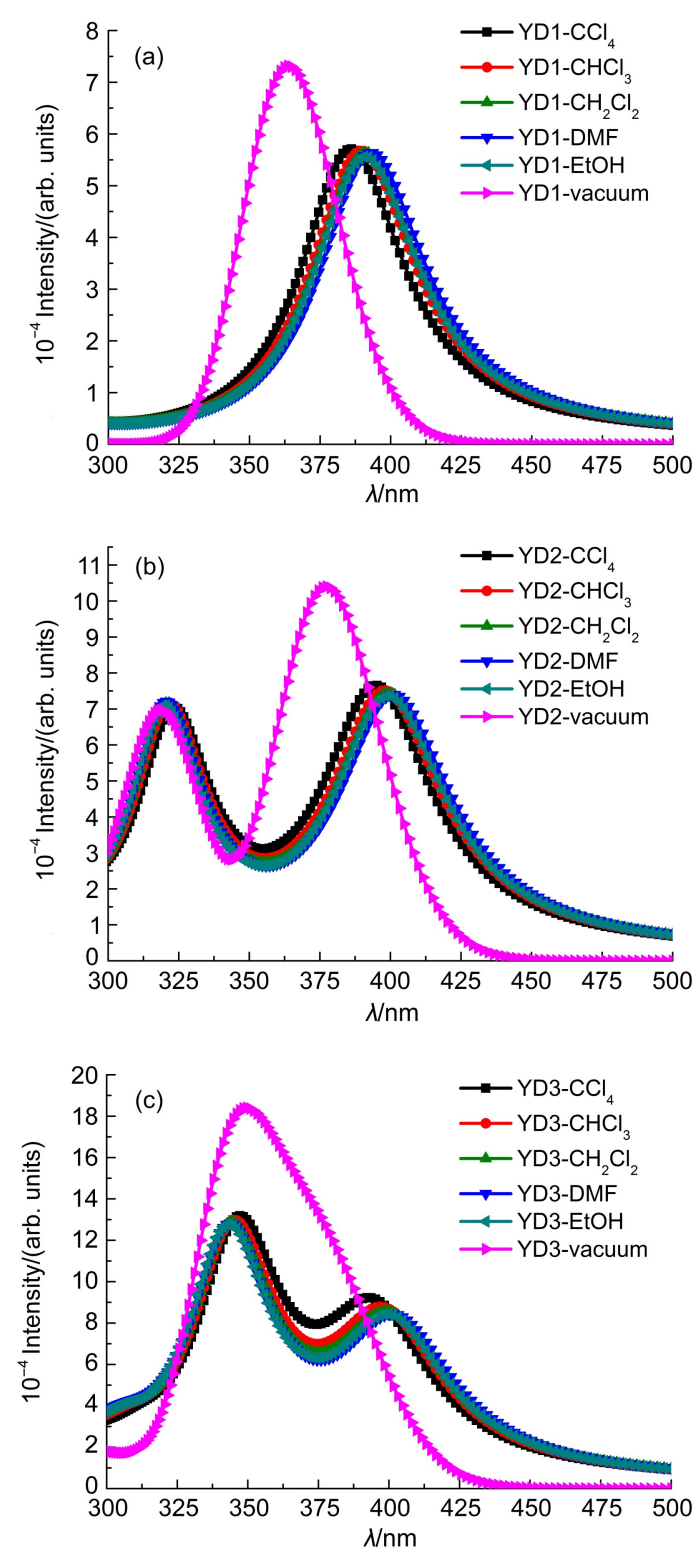

Fig.4 Simulated absorption spectra of sensitizers in vacuum and solvent (a) YD1; (b) YD2; (c) YD3

limitation between HOMO and LUMO orbital. By analyzing the simulated absorption spectra of the three free sensitizers in vacuum, we can conclude that YD2, which contains one TTF unit, has broader absorption band and higher oscillator strength than YD1. With the increasing number of TTF units are introduced (YD3), the absorption band gets broader and absorption strength increases systematically.

The absorption spectra of YD1-( $\left.\mathrm{TiO}_{2}\right)_{9}$, YD2-( $\left(\mathrm{TiO}_{2}\right)_{9}$ and YD3$\left(\mathrm{TiO}_{2}\right)_{9}$ in vacuum are also simulated. Compared with free sensitizers, the absorption spectra of $\mathrm{YD} 1-\left(\mathrm{TiO}_{2}\right)_{9}, \mathrm{YD} 2-\left(\mathrm{TiO}_{2}\right)_{9}$, and YD3- $\left(\mathrm{TiO}_{2}\right)_{9}$ have red shifts about 28,29 , and $28 \mathrm{~nm}$, respectively. The main reason may be the narrowed energy gaps which are caused by the sharply decreased LUMOs energy when the three sensitizers bind to $\left(\mathrm{TiO}_{2}\right)_{9}$ clusters. What's more, the simulated UVVis absorption spectra of free sensitizers YD1 -3 and adsorbed
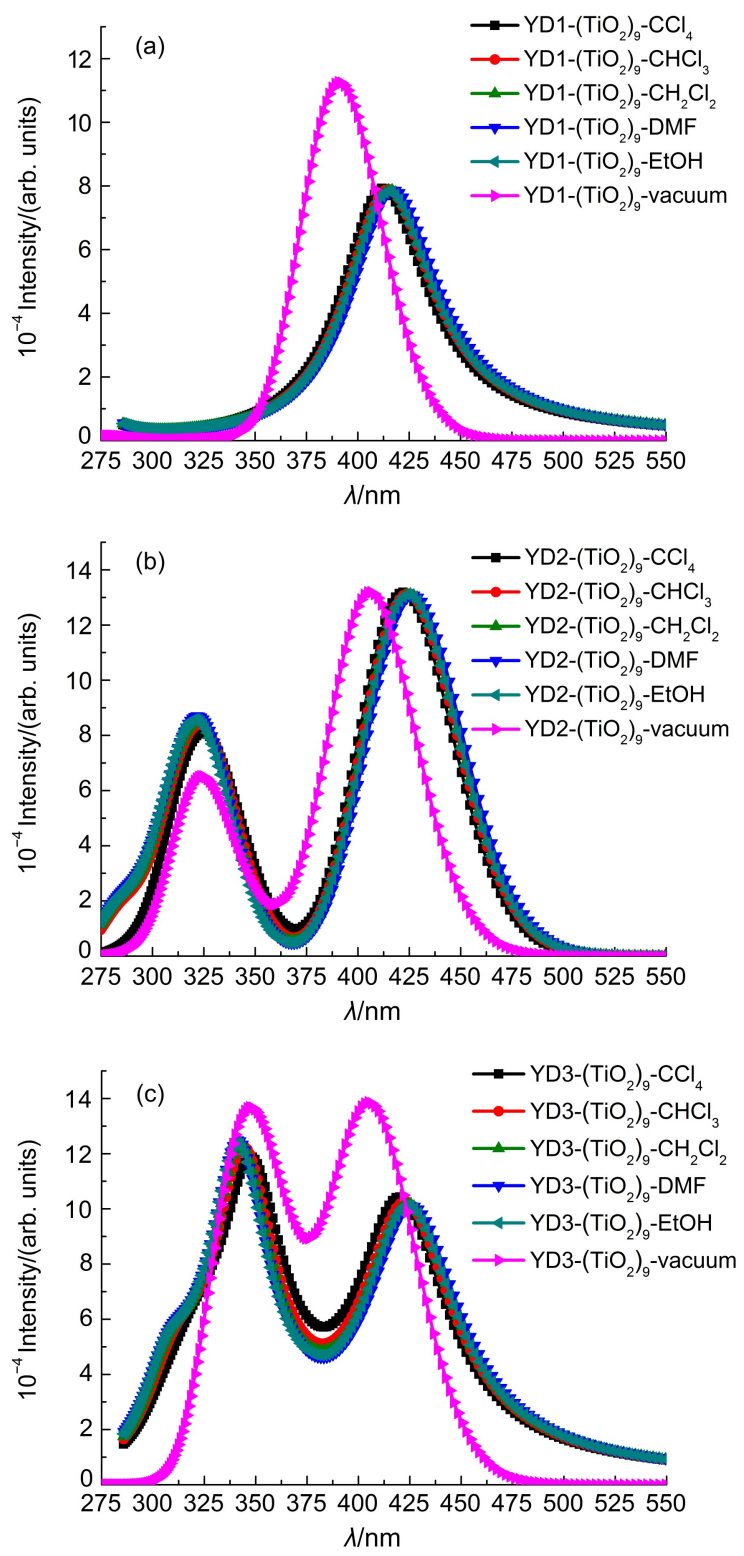

Fig.5 Simulated absorption spectra of $\mathrm{YD}-\left(\mathrm{TiO}_{2}\right)_{9}$ in vacuum and solvent

(a) YD1-( $\left(\mathrm{TiO}_{2}\right)_{9}$; (b) YD2-( $\left.\mathrm{TiO}_{2}\right)_{9}$; (c) YD3-( $\left.\mathrm{TiO}_{2}\right)_{9}$

sensitizers $\mathrm{YD} 1-3-\left(\mathrm{TiO}_{2}\right)_{9}$ in five solvents $\left(\mathrm{EtOH}, \mathrm{CH}_{2} \mathrm{Cl}_{2}, \mathrm{CHCl}_{3}\right.$, $\mathrm{CCl}_{4}$, and DMF) are shown in Fig.4 and Fig.5. Compared with the absorption spectra in vacuum, the absorption peaks in solvents have red shifted and the absorption bands have further broadened. In addition, it is worthy to note that the simulated absorption spectra in DMF express a superior red-shift compared with others while the absorption spectra in $\mathrm{CCl}_{4}$ show the most blue-shift.

Table 2 Important optimized bond distance, molecule adsorption energy of YD1-( $\left.\mathrm{TiO}_{2}\right)_{38}$, YD2-( $\left.\mathrm{TiO}_{2}\right)_{38}$, and

YD3- $\left(\mathrm{TiO}_{2}\right)_{38}$ by $\mathrm{Dmol}^{3}$ calculation

\begin{tabular}{cccc}
\hline Dye- $\left(\mathrm{TiO}_{2}\right)_{38}$ & $\gamma(\mathrm{Ti}-\mathrm{O}) / \mathrm{nm}$ & $\gamma(\mathrm{Ti}-\mathrm{O}) / \mathrm{nm}$ & $E_{\text {ads }} /\left(\mathrm{kJ} \cdot \mathrm{mol}^{-1}\right)$ \\
\hline $\mathrm{YD} 1-\left(\mathrm{TiO}_{2}\right)_{38}$ & 0.2189 & 0.2150 & 186.77 \\
$\mathrm{YD} 2-\left(\mathrm{TiO}_{2}\right)_{38}$ & 0.2132 & 0.2171 & 117.48 \\
$\mathrm{YD} 3-\left(\mathrm{TiO}_{2}\right)_{38}$ & 0.2246 & 0.2130 & 143.48 \\
\hline
\end{tabular}


Table 3 Calculated excitation energy $\left(E_{v}\right)$, maximum absorption wavelength $\left(\lambda_{\max }\right)$, major assignment, oscillator strength $(f)$, LHE (H = HOMO and L = LUMO), and estimated electrochemical parameters for YD1 -3 in DMF

\begin{tabular}{|c|c|c|c|c|c|c|c|c|}
\hline Dye & $E_{\mathrm{v}} / \mathrm{eV}$ & $\lambda_{\max } / \mathrm{nm}$ & Major assignment & $f$ & LHE & $E^{\mathrm{dyy}} / \mathrm{eV}$ & $E^{\mathrm{dye} e^{*}} / \mathrm{eV}$ & $\Delta G^{\text {inject }} / \mathrm{eV}$ \\
\hline YD1 & 3.15 & 393.1 & $\mathrm{H} \rightarrow \mathrm{L}(+92 \%)$ & 1.1382 & 0.93 & 5.52 & 2.37 & -1.63 \\
\hline YD2 & 3.09 & 401.3 & $\mathrm{H}-1 \rightarrow \mathrm{L}(+42 \%), \mathrm{H} \rightarrow \mathrm{L}(+44 \%)$ & 1.4184 & 0.96 & 5.15 & 2.06 & -1.94 \\
\hline YD3 & 3.61 & 343.5 & $\mathrm{H} \rightarrow \mathrm{L}+1(+63 \%)$ & 2.3699 & 0.99 & 5.22 & 1.61 & -2.39 \\
\hline
\end{tabular}

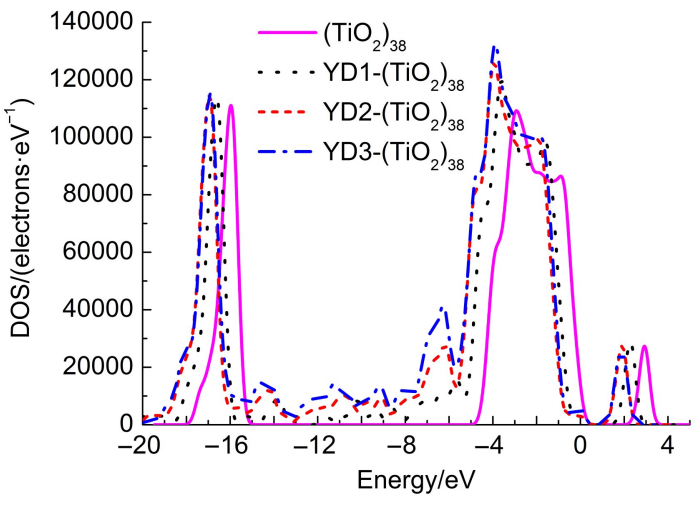

Fig.6 Density of states of bare $\left(\mathrm{TiO}_{2}\right)_{38}, \mathrm{YD1}-\left(\mathrm{TiO}_{2}\right)_{38}$, $\mathrm{YD} 2-\left(\mathrm{TiO}_{2}\right)_{38}$, and $\mathrm{YD3}_{-}\left(\mathrm{TiO}_{2}\right)_{38}$

There are two reasons to explain this phenomenon: First, the different solubilities which is related to the dye aggregation, adsorption mode for the sensitizers would affect the absorption properties $^{50}$; second, the intermolecular hydrogen bonding interaction between the sensitizers and solvent molecules could also influence the absorption spectra: if the electronic spectral peak shifts to the red due to intermolecular hydrogen bonding, the hydrogen bond in the corresponding electronic excited state will be strengthened; otherwise, an electronic spectral blue-shift will indicate that the intermolecular hydrogen bond is weakened in the corresponding electronic excited state ${ }^{51}$.

\subsection{Adsorption of dyes on $\left(\mathrm{TiO}_{2}\right)_{38}$ clusters}

In order to investigate the effects of auxiliary electron donor on morphologies of the dyes on $\mathrm{TiO}_{2}$ surface, sensitizers YD1 - 3 adsorbed on the $\left(\mathrm{TiO}_{2}\right)_{38}$ cluster with bidentate bridging mode ${ }^{52}$ were simulated by $\mathrm{Dmol}^{3}$ program. The optimized structures of YD1 -3 are shown in Fig.S2 and the corresponding data are listed in Table 2. All of the sensitizers show the $\mathrm{Ti}-\mathrm{O}$ bond distances in the range $0.2130-0.2246 \mathrm{~nm}$ and the absorption energies $\left(E_{\text {ads }}\right)$ of YD1, YD2, and YD3 on $\mathrm{TiO}_{2}$ surface were calculated to be $186.77,117.48$, and $143.48 \mathrm{~kJ} \cdot \mathrm{mol}^{-1}$, respectively. This implies that $\mathrm{YD} 1-3$ could adsorb on the $\mathrm{TiO}_{2}$ anatase (101) surface firmly.

Besides, density of states (DOS) for the $\mathrm{TiO}_{2}$ and sensitizers$\mathrm{TiO}_{2}$ are shown in Fig.6. As seen in Fig.6, some small peaks in the band gap are observed after the sensitizers adsorbed on the $\mathrm{TiO}_{2}$ surface, which could reduce the semiconductor band gap of corresponding $\mathrm{TiO}_{2}$. Moreover, the widths of both $\mathrm{VB}$ and $\mathrm{CB}$ of the sensitizer- $\mathrm{TiO}_{2}$ are broadened, implying a strong coupling of the adsorbate molecular orbital with the substrate bands. The narrowed band gap and the broadened VB and $\mathrm{CB}$ are helpful for the transmission of electrons ${ }^{53}$. $V_{\mathrm{oc}}$ is determined by the semiconductor and the redox couple, which could affect the $\eta$ of the DSSCs to a great extent. And enhancement of the $V_{\text {oc }}$ value is relevant to the semiconductor band edge toward negative potentials ${ }^{54}$. From Fig.6, YD2 and YD3 show a more negative potentials shift of CB edge of $\mathrm{TiO}_{2}$ compared that of YD1, which means that YD2 and YD3 with TTF units as the auxiliary electron donor should exhibit a higher $V_{\text {oc }}$ than that of YD $1^{55}$.

\subsection{Photovoltaic performance based on sensitizers YD1-3: factors influencing $J_{\mathrm{sc}}$}

As discussed above, LHE and $\Phi_{\text {inject }}$ are the two main factors affecting $J_{\text {sc. }}$ Thus, we chose the simulated the UV-Vis spectra of YD1-3 in DMF solution for they could present the best performance among all the five solvents in theory. The corresponding parameters are summarized in Table 3. From Eq.(3), we could know that the high LHE value and $\Phi_{\text {inject }}$ could enhance the $J_{\text {sc }}$ and then increase the $\eta$ of DSSCs. As shown in Table 3, the LHE values of the three sensitizers are in range $0.93-0.99$ and lay in the order of YD1 $<$ YD2 < YD3, implying that the LHE increases systematic with the increasing number of TTF units. This indicates that the introduction of auxiliary electron donor (TTF) plays an important role in improving the LHE values. From Eq.(3) and Eq. (5), it is obvious that a larger $\Phi_{\text {inject }}$ which is related to the $\Delta G^{\text {inject }}$ could also gain a high $J_{\text {sc. }}$ As seen in Table 3 , the estimated $\Delta G^{\text {inject }}$ of the three sensitizers are all negative values, guaranteeing that the electron could inject from the sensitizers to $\mathrm{TiO}_{2}$ effectively. What's more, the calculated $\Delta G^{\text {inject }}$ decrease in the order YD3 > YD2 > YD1. From the above results, it is reasonable to believe that the DSSC based on YD3 should have a higher $J_{\mathrm{sc}}$ for its superior LHE and higher $\Delta G^{\text {inject }}$ compared with the others. And this also means that TTF units which act as the auxiliary electron donors could improve the $J_{\mathrm{sc}}$ of the corresponding sensitizer based DSSCs for its strong electron donor ability.

\section{Conclusions}

Two novel potential sensitizers (YD2, YD3), which contain triphenylamine as main donor units and different number of tetrathiafulvalene (TTF) units as auxiliary donor, have been designed and studied by DFT and TD-DFT. The DFT and TD-DFT calculation results indicate that the introduction of TTF units as the auxiliary electron donor could not only increase the steric hindrance but also improve the performance of absorption spectra. And they are systematically enhanced with the increasing number of TTF units. Moreover, the estimated LHE, $\Delta G^{\text {inject }}$ values and DOS calculations indicate that YD2 and YD3 should present a higher $J_{\text {sc }}$ and $V_{\text {oc }}$ than YD1 for the presence of TTF units. That is to say, TTF unit is theoretically proved that it could be used as the auxiliary electron donor and play a crucial role in improving the 
performance of the corresponding sensitizers based DSSCs in theory.

Supporting Information: The optimized geometries of complexes YD1-3 adsorbed on $\left(\mathrm{TiO}_{2}\right)_{38}(101)$ surface by $\mathrm{DMol}^{3}$ calculation, molecular orbital energy diagram of YD1 -3 before and after binding to $\left(\mathrm{TiO}_{2}\right)_{9}$ clusters and electronic transition configurations, computed excitation energies and oscillator strengths $(f)$ for the optical transitions with $f>0.01$ of the absorption bands in visible and near UV region for YD1 -3 before and after binding to $\left(\mathrm{TiO}_{2}\right)_{9}$ clusters in vacuum have been included. This information is available free of charge via the internet at http:// www.whxb.pku.edu.cn.

\section{References}

(1) O'Regan, B.; Grätzel, M. Nature 1991, 353, 737. doi: 10.1038/ $353737 \mathrm{a} 0$

(2) Mathew, S.; Yella, A.; Gao, P.; Humphry-Baker, R.; Curchod, B F. E.; Ashari-Astani, N.; Tavernelli, I.; Rothlisberger, U.; Nazeeruddin, M. K.; Grätzel, M. Nat. Chem. 2014, 6, 242. doi: $10.1038 /$ nchem. 1861

(3) Yu, Q.; Wang, Y.; Yi, Z.; Zu, N.; Zhang, J.; Zhang, M.; Wang, P. ACS Nano 2010, 4, 6032. doi: 10.1021/nn101384e

(4) Yao, Z.; Zhang, M.; Wu, H.; Yang, L.; Li, R.; Wang, P. J. Am. Chem. Soc. 2015, 137, 3799. doi: 10.1021/jacs.5b01537

(5) Zhou, L.; Jia, C.; Wan, Z.; Li, Z.; Bai, J.; Zhang, L.; Zhang, J.; Yao, X. Dyes Pigments 2012, 95, 743. doi: 10.1016/j. dyepig.2012.05.007

(6) Hara, K.; Wang, Z. S.; Cui, Y.; Furube, A.; Koumura, N. Energy Environ. Sci. 2009, 2, 1109. doi: 10.1039/b907486d

(7) Higashijima, S.; Inoue, Y.; Miura, H.; Kubota, Y.; Funabiki, K.; Yoshida, T.; Matsui, M. RSC Adv. 2012, 2, 2721. doi: 10.1039/ c2ra01358d

(8) Kim, S.; Lee, J. K.; Kang, S. O.; Ko, J.; Yum, J. H.; Fantacci, S.; De Angelis, F.; Di Censo, D.; Nazeeruddin, M. K.; Grätzel, M. J. Am. Chem. Soc. 2006, 128, 16701. doi: 10.1021/ja066376f

(9) Talebnia, F.; Nourmohammadian, F.; Bastani, S. Prog. Org. Coat. 2014, 77, 1351. doi: 10.1016/j.porgcoat.2014.04.022

(10) Guillen, E.; Azaceta, E.; Peter, L. M.; Zukal, A.; Tena-Zaera, R.; Anta, J. A. Energy Environ. Sci. 2011, 4, 3400. doi: 10.1039/ $\mathrm{c} 0 \mathrm{ee} 00500 \mathrm{~b}$

(11) Xu, J.; Zhang, H.; Liang, G.; Wang, L.; Xu, W.; Cui, W.; Li, Z. J. Serb. Chem. Soc. 2010, 75, 259. doi: 10.2298/jsc1002259x

(12) Tan, Y.; Liang, M.; Lu, Z.; Zheng, Y.; Tong, X.; Sun, Z.; Xue, S. Org. Lett. 2014, 16, 3978. doi: 10.1021/o15018036

(13) Wan, Z.; Jia, C.; Duan, Y.; Chen, X.; Lin, Y.; Shi, Y. Org. Electron. 2013, 14, 2132. doi: 10.1016/j.orgel.2013.05.011

(14) Zeng, W.; Cao, Y.; Bai, Y.; Wang, Y.; Shi, Y.; Zhang, M.; Wang, F.; Pan, C.; Wang, P. Chem. Mater. 2010, 22, 1915. doi: 10.1021/ cm9036988

(15) Xu, J.; Wang, L.; Liang, G. J.; Bai, Z. K.; Wang, L. X.; Xu, W. L.; Shen, X. L. Spectrochim. Acta A 2011, 78, 287. doi: 10.1016/ j.saa.2010.10.008

(16) Chen, C.; Liao, J. Y.; Chi, Z.; Xu, B.; Zhang, X.; Kuang, D. B.; Zhang, Y.; Liu, S.; Xu, J. J. Mater. Chem. 2012, 22, 8994. doi: $10.1039 / \mathrm{c} 2 \mathrm{jm} 30254 \mathrm{c}$

(17) Chen, X.; Jia, C.; Wan, Z.; Yao, X. Dyes Pigments 2014, 104, 48. doi: 10.1016/j.dyepig.2013.12.024

(18) Wan, Z.; Jia, C.; Zhang, J.; Duan, Y.; Lin, Y.; Shi, Y. J. Power Sources 2012, 199, 426. doi: 10.1016/j.jpowsour.2011.10.062

(19) Tarsang, R.; Promarak, V.; Sudyoadsuk, T.; Namuangruk, S.; Jungsuttiwong, S. J. Photochem. Photobiol. A 2014, 273, 8. doi: 10.1016/j.jphotochem.2013.09.002

(20) Wang, C.; Dong, H.; Hu, W.; Liu, Y.; Zhu, D. Chem. Rev. 2012, 112, 2208. doi: 10.1021/cr100380z

(21) Pointillart, F.; Guennic, B.; Cador, O.; Maury, O.; Ouahab, L. Acc. Chem. Res. 2015, 48, 2834. doi: 10.1021/acs.accounts. $5 \mathrm{~b} 00296$

(22) Jia, C.; Liu, S. X.; Tanner, C.; Leiggener, C.; Neels, A.; Sanguinet, L.; Levillain, E.; Leutwyler, S.; Hauser, A.; Decurtins, S. Chem. Eur. J. 2007, 13, 3804. doi: 10.1002/ chem.200601561

(23) Pop, F.; Amacher, A.; Avarvari, N.; Ding, J.; Daku, L. M. L.; Hauser, A.; Koch, M.; Hauser, J.; Liu, S. X.; Decurtins, S. Chem. Eur. J. 2013, 19, 2504. doi: 10.1002/chem.201202742

(24) Wenger, S.; Bouit, P.; Chen, Q.; Teuscher, J.; Di Censo, D.; Humphry-Baker, R.; Moser, J.; Delgado, J.; Martin, N.; Zakeeruddin, S.; Grätzel, M. J. Am. Chem. Soc. 2010, 132, 5164. doi: 10.1021/ja909291h

(25) Amacher, A.; Yi, C.; Yang, J.; Bircher, M. P.; Fu, Y.; Cascella, M.; Grätzel, M.; Decurtins, S.; Liu, S. X. Chem. Commun. 2014, 50, 6540. doi: $10.1039 / \mathrm{c} 4 \mathrm{cc} 02696 \mathrm{a}$

(26) Chen, X.; Jia, C.; Wan, Z.; Zhang, J.; Yao, X. Spectrochim. Acta $A$ 2014, 123, 282. doi: 10.1016/j.saa.2013.12.072

(27) Liang, G.; Yuan, Y.; Wang, D.; Zhong, Z.; Xu, J. Monatsh. Chem. 2014, 145, 1737. doi: 10.1007/s00706-014-1260-3

(28) Sanchez-de-Armas, R.; San Miguel, M. A.; Oviedo, J.; Sanz, J. F. Phys. Chem. Chem. Phys. 2012, 14, 225. doi: 10.1039/ c1cp22058f

(29) Sánchez-de-Armas, R. O.; Oviedo López, J.; A. San-Miguel, M.; Sanz, J. F.; Ordejón, P.; Pruneda, M. J. Chem. Theory Comput. 2010, 6, 2856. doi: 10.1021/ct100289t

(30) Zhan, W. S.; Li, R.; Pan, S.; Guo, Y. N.; Zhang, Y. Acta Phys. Chim. Sin. 2013, 29, 255. [詹卫伸, 李 睿, 潘 石, 郭英楠, 张 毅. 物理化学学报, 2013, 29, 255.] doi: 10.3866/PKU. WHXB201211221

(31) Zhan, W. S.; Pan, S.; Wang, Q.; Li, H.; Zhang, Y. Acta Phys. -Chim. Sin. 2012, 28, 78. [詹卫伸, 潘 石, 王 乔, 李 宏, 张 毅. 物理化学学报, 2012, 28, 78.] doi: 10.3866/ PKU.WHXB20122878

(32) Yanai, T.; Tew, D. P.; Handy, N. C. Chem. Phys. Lett. 2004, 393 51. doi: 10.1016/j.cplett.2004.06.011

(33) Pastore, M.; Mosconi, E.; De Angelis, F.; Grätzel, M. J. Phys. 
Chem. C 2010, 114, 7205. doi: 10.1021/jp100713r

(34) Tomasi, J.; Mennucci, B.; Cammi, R. Chem. Rev. 2005, 105, 2999. doi: $10.1021 / \mathrm{cr} 9904009$

(35) Zhan, W. S.; Pan, S.; Li. Y. Z.; Chen, M. D. Acta Phys. -Chim. Sin. 2010, 26, 1408. [詹卫伸, 潘 石, 李源作, 陈茂笃. 物理化 学学报, 2010, 26, 1408.] doi: 10.3866/PKU.WHXB20100518

(36) Frisch, M. J.; Trucks, G. W.; Schlegel, H. B.; et al. Gaussian 09 Revision A.2; Gaussian Inc.: Wallingford, CT, 2009.

(37) Namuangruk, S.; Fukuda, R.; Ehara, M.; Meeprasert, J.; Khanasa, T.; Morada, S.; Kaewin, T.; Jungsuttiwong, S.; Sudyoadsuk, T.; Promarak, V. J. Phys. Chem. C 2012, 116, 25653. doi: $10.1021 / \mathrm{jp} 304489 \mathrm{t}$

(38) Inada, Y.; Orita, H. J. Comput. Chem. 2008, 29, 225. doi: $10.1002 /$ jcc. 20782

(39) Perdew, J. P.; Burke, K.; Ernzerhof, M. Phys. Rev. Lett. 1996, 77, 3865. doi: 10.1103/PhysRevLett.77.3865

(40) Delley, B. Phys. Rev. B 2002, 66, 155125. doi: 10.1103/ PhysRevB.66.155125

(41) Mehmood, U.; Hussein, I. A.; Daud, M.; Ahmed, S.; Harrabi, K Dyes Pigments 2015, 118, 152. doi: 10.1016/j. dyepig.2015.03.003

(42) Fitri, A.; Benjelloun, A. T.; Benzakour, M.; McHarfi, M.; Hamidi, M.; Bouachrine, M. Spectrochim. Acta A 2014, 124, 646. doi: 10.1016/j.saa.2014.01.052

(43) Asbury, J. B.; Wang, Y. Q.; Hao, E. C.; Ghosh, H. N.; Lian, T. Q. Res. Chem. Intermed. 2001, 27, 393. doi: 10.1163/ 156856701104202255
(44) Lundqvist, M. J.; Nilsing, M.; Persson, P.; Lunell, S. Int. J. Quantum. Chem. 2006, 106, 3214. doi: 10.1002/qua.21088

(45) Monari, A.; Assfeld, X.; Beley, M.; Gros, P. C. J. Phys. Chem. A 2011, 115, 3596. doi: 10.1021/jp201058v

(46) Jean, J. M.; Hall, K. B. Proc. Natl. Acad. Sci. U. S. A. 2001, 98, 37. doi: $10.1073 /$ pnas. 011442198

(47) Chen, X. M.; Jia, C. Y.; Wan, Z. Q.; Yao, X. J. Acta Phys. -Chim. Sin. 2014, 30, 273. [陈喜明, 贾春阳, 万中全, 姚小军. 物理化 学学报, 2014, 30, 273.] doi: 10.3866/PKU.WHXB201311262

(48) Kafafy, H.; Wu, H.; Peng, M.; Hu, H.; Yan, K.; El-Shishtawy, R. M.; Zou, D. Int. J. Photoenergy 2014, 2014, 548914. doi: 10.1155/2014/548914

(49) Mosconi, E.; Selloni, A.; De Angelis, F. J. Phys. Chem. C 2012, 116, 5932. doi: 10.1021/jp209420h

(50) Jeon, B. C.; Kim, M. S.; Cho, M. J.; Choi, D. H.; Ahn, K. S.; Kim, J. H. Synth. Met. 2014, 188, 130. doi: 10.1016/j. synthmet.2013.12.006

(51) Zhao, G.; Han, K. Acc. Chem. Res. 2012, 45, 404. doi: 10.1021/ ar200135h

(52) Khoudiakov, M.; Parise, A. R.; Brunschwig, B. S. J. Am. Chem. Soc. 2003, 125, 4637. doi: 10.1021/ja0299607

(53) Labat, F.; Adamo, C. J. Phys. Chem. C 2007, 111, 15034. doi: $10.1021 / \mathrm{jp} 0743491$

(54) Kusama, H.; Orita, H.; Sugihara, H. Sol. Energy Mater. Sol. Cells 2008, 92, 84. doi: 10.1016/j.solmat.2007.09.004

(55) Zhang, Q.; Zhu, W.; Fang, M.; Yin, F.; Li, C. Spectrochim. Acta A 2015, 135, 379. doi: 10.1016/j.saa.2014.06.159 
Supporting Information for Acta Phys. -Chim. Sin. 2016, 32 (8): 1990-1998

doi: $10.3866 /$ PKU.WHXB201605031

\title{
新型四硫富瓦烯-三苯胺类光敏染料理论研究
}

翁小龙 $^{1}$ 王 艳 $^{1}$ 贾春阳 ${ }^{1, *}$ 万中全 ${ }^{1} \quad$ 陈喜明 $^{2}$ 姚小军 $^{3}$

( ${ }^{1}$ 电子科技大学微电子与固体电子学院, 电子薄膜与集成器件国家重点实验室, 国家电磁辐射控制材料工 程技术研究中心，成都 610054; ${ }^{2}$ 中车株洲电力机车研究所有限公司, 湖南 株洲 412001;

3 兰州大学化学化工学院, 功能有机分子化学国家重点实验室, 兰州 730000)

\section{Theoretical Investigation of Novel Tetrathiafulvalene- Triphenylamine Sensitizers}

\author{
WENG Xiao-Long $^{1} \quad$ WANG Yan $^{1} \quad$ JIA Chun-Yang, ${ }^{1, *} \quad$ WAN Zhong-Quan ${ }^{1}$ \\ CHEN Xi-Ming ${ }^{2} \quad$ YAO Xiao-Jun ${ }^{3}$
}

( ${ }^{1}$ State Key Laboratory of Electronic Thin Films and Integrated Devices, National Engineering Research Center of Electromagnetic Radiation Control Materials, School of Microelectronics and Solid-State Electronics, University of Electronic Science and Technology of China, Chengdu 610054, P. R. China; ${ }^{2}$ CSR Zhuzhou Electric Locomotive Research Institute Co. Ltd., Zhuzhou 412001, Hunan Province, P. R. China; ${ }^{3}$ State Key Laboratory of Applied Organic Chemistry, School of Chemistry and Chemical Engineering, Lanzhou University, Lanzhou 730000, P. R. China)

${ }^{*}$ Corresponding author. Email: cyjia@uestc.edu.cn; Tel: +86-28-83201991; Fax: +86-28-83202569. 
Table S1 Electronic transition configurations, computed excitation energies and oscillator strengths $(f)$ for the optical transitions with $f>0.01$ of the absorption bands in visible and near UV region for YD1-3 before and after binding to $\left(\mathrm{TiO}_{2}\right)_{9}$ clusters in vacuum. $(\mathrm{H}=$ HOMO, L = LUMO, L + 1 = LUMO + 1, etc.)

\begin{tabular}{|c|c|c|c|c|c|}
\hline Dye & $\lambda / \mathrm{nm}$ & $E / \mathrm{eV}$ & $f$ & \multicolumn{2}{|c|}{ Composition } \\
\hline \multirow{3}{*}{ YD1 } & 363.8 & 3.41 & 1.0097 & $\mathrm{H} \rightarrow \mathrm{L}(+93 \%)$ & \\
\hline & 261.4 & 4.74 & 0.1575 & $\begin{array}{l}\mathrm{H} \rightarrow \mathrm{L}+2(+44 \%) \\
\mathrm{H}-4 \rightarrow \mathrm{L}(+7 \%)\end{array}$ & $\mathrm{H} \rightarrow \mathrm{L}+1(+32 \%)$ \\
\hline & 252.3 & 4.92 & 0.1143 & $\mathrm{H}-1 \rightarrow \mathrm{L}(+74 \%)$ & $\mathrm{H} \rightarrow \mathrm{L}+3(+5 \%)$ \\
\hline \multirow[t]{5}{*}{ YD2 } & 377.2 & 3.29 & 1.4272 & $\begin{array}{l}\mathrm{H}-1 \rightarrow \mathrm{L}(+65 \%) \\
\mathrm{H}-2 \rightarrow \mathrm{L}(5 \%)\end{array}$ & $\mathrm{H} \rightarrow \mathrm{L}(+17 \%)$ \\
\hline & 319.3 & 3.88 & 0.9357 & $\begin{array}{l}\mathrm{H} \rightarrow \mathrm{L}+1(+50 \%) \\
\mathrm{H}-1 \rightarrow \mathrm{L}(+10 \%)\end{array}$ & $\mathrm{H}-1 \rightarrow \mathrm{L}+1(+14 \%)$ \\
\hline & 294.7 & 4.21 & 0.1185 & $\mathrm{H} \rightarrow \mathrm{L}(+59 \%)$ & $\mathrm{H}-1 \rightarrow \mathrm{L}+1(+25 \%)$ \\
\hline & 257.0 & 4.82 & 0.1109 & $\begin{array}{l}\mathrm{H}-6 \rightarrow \mathrm{L}(+19 \%) \\
\mathrm{H}-5 \rightarrow \mathrm{L}(11 \%)\end{array}$ & $\begin{array}{l}\mathrm{H}-3 \rightarrow \mathrm{L}+1(+16 \%) \\
\mathrm{H}-2 \rightarrow \mathrm{L}(7 \%)\end{array}$ \\
\hline & 244.6 & 5.07 & 0.4106 & $\begin{array}{l}\mathrm{H}-3 \rightarrow \mathrm{L}(6 \%) \\
\mathrm{H} \rightarrow \mathrm{L}+8(+15 \%) \\
\mathrm{H}-2 \rightarrow \mathrm{L}+1(+8 \%) \\
\mathrm{H} \rightarrow \mathrm{L}+1(7 \%) \\
\mathrm{H}-6 \rightarrow \mathrm{L}(6 \%)\end{array}$ & $\begin{array}{l}\mathrm{H}-2 \rightarrow \mathrm{L}+1(6 \%) \\
\mathrm{H} \rightarrow \mathrm{L}+9(+9 \%) \\
\mathrm{H}-3 \rightarrow \mathrm{L}+2(8 \%) \\
\mathrm{H}-2 \rightarrow \mathrm{L}+2(7 \%)\end{array}$ \\
\hline \multirow[t]{4}{*}{ YD3 } & 378.1 & 3.28 & 1.3770 & $\begin{array}{l}\mathrm{H}-2 \rightarrow \mathrm{L}(+57 \%) \\
\mathrm{H}-4 \rightarrow \mathrm{L}(6 \%)\end{array}$ & $\mathrm{H} \rightarrow \mathrm{L}(+21 \%)$ \\
\hline & 345.7 & 3.59 & 2.2794 & $\begin{array}{l}\mathrm{H} \rightarrow \mathrm{L}+1(+39 \%) \\
\mathrm{H}-1 \rightarrow \mathrm{L}+2(7 \%)\end{array}$ & $\mathrm{H}-2 \rightarrow \mathrm{L}+1(+30 \%)$ \\
\hline & 290.9 & 4.26 & 0.1316 & $\begin{array}{l}\mathrm{H} \rightarrow \mathrm{L}(+59 \%) \\
\mathrm{H}-2 \rightarrow \mathrm{L}(6 \%)\end{array}$ & $\mathrm{H} \rightarrow \mathrm{L}+2(+6 \%)$ \\
\hline & 265.7 & 4.67 & 0.1253 & $\begin{array}{l}\mathrm{H}-4 \rightarrow \mathrm{L}+1(+15 \%), \\
\mathrm{H}-18 \rightarrow \mathrm{L}(7 \%), \\
\mathrm{H}-14 \rightarrow \mathrm{L}(+5 \%)\end{array}$ & $\begin{array}{l}\mathrm{H}-2 \rightarrow \mathrm{L}+9(11 \%) \\
\mathrm{H}-3 \rightarrow \mathrm{L}(6 \%)\end{array}$ \\
\hline YD1-( $\left.\mathrm{TiO}_{2}\right)_{9}$ & 391.0 & 3.17 & 1.5535 & $\begin{array}{l}\mathrm{H} \rightarrow \mathrm{L}+10(+31 \%) \\
\mathrm{H} \rightarrow \mathrm{L}+6(+15 \%)\end{array}$ & $\begin{array}{l}\mathrm{H} \rightarrow \mathrm{L}+8(28 \%) \\
\mathrm{H} \rightarrow \mathrm{L}+5(+8 \%)\end{array}$ \\
\hline \multirow[t]{4}{*}{ YD2- $\left(\mathrm{TiO}_{2}\right)_{9}$} & 406.2 & 3.05 & 1.7861 & $\begin{array}{l}\mathrm{H}-1 \rightarrow \mathrm{L}+8(+18 \%) \\
\mathrm{H}-1 \rightarrow \mathrm{L}+5(13 \%)\end{array}$ & $\begin{array}{l}\mathrm{H}-1 \rightarrow \mathrm{L}+6(+15 \%) \\
\mathrm{H}-1 \rightarrow \mathrm{L}+9(13 \%)\end{array}$ \\
\hline & 348.3 & 3.56 & 0.1314 & $\begin{array}{l}\mathrm{H} \rightarrow \mathrm{L}+5(+36 \%) \\
\mathrm{H} \rightarrow \mathrm{L}+8(13 \%)\end{array}$ & $\begin{array}{l}\mathrm{H} \rightarrow \mathrm{L}+6(21 \%) \\
\mathrm{H} \rightarrow \mathrm{L}+9(+5 \%)\end{array}$ \\
\hline & 323.6 & 3.83 & 0.6300 & $\begin{array}{l}\mathrm{H} \rightarrow \mathrm{L}+24(+31 \%), \\
\mathrm{H}-1 \rightarrow \mathrm{L}+24(+9 \%)\end{array}$ & $\begin{array}{l}\mathrm{H} \rightarrow \mathrm{L}+8(+30 \%) \\
\mathrm{H} \rightarrow \mathrm{L}+23(7 \%)\end{array}$ \\
\hline & 316.3 & 3.92 & 0.1362 & $\begin{array}{l}\mathrm{H} \rightarrow \mathrm{L}+9(+75 \%) \\
\mathrm{H} \rightarrow \mathrm{L}+8(+5 \%)\end{array}$ & $\mathrm{H} \rightarrow \mathrm{L}+24(7 \%)$ \\
\hline \multirow[t]{4}{*}{ YD3- $\left(\mathrm{TiO}_{2}\right)_{9}$} & 406.3 & 3.05 & 1.8525 & $\begin{array}{l}\mathrm{H}-2 \rightarrow \mathrm{L}+5(+21 \%), \\
\mathrm{H}-2 \rightarrow \mathrm{L}+6(+11 \%) \\
\mathrm{H}-2 \rightarrow \mathrm{L}+9(8 \%)\end{array}$ & $\begin{array}{l}\mathrm{H}-2 \rightarrow \mathrm{L}+8(12 \%) \\
\mathrm{H} \rightarrow \mathrm{L}+5(+8 \%)\end{array}$ \\
\hline & 355.4 & 3.49 & 1.0475 & $\begin{array}{l}\mathrm{H}-1 \rightarrow \mathrm{L}+5(+24 \%) \\
\mathrm{H}-1 \rightarrow \mathrm{L}+6(+9 \%) \\
\mathrm{H}-1 \rightarrow \mathrm{L}+8(8 \%)\end{array}$ & $\begin{array}{l}\mathrm{H} \rightarrow \mathrm{L}+21(+15 \%) \\
\mathrm{H}-2 \rightarrow \mathrm{L}+21(+8 \%)\end{array}$ \\
\hline & 344.1 & 3.60 & 0.1062 & $\begin{array}{l}\mathrm{H} \rightarrow \mathrm{L}+5(+51 \%) \\
\mathrm{H} \rightarrow \mathrm{L}+8(5 \%)\end{array}$ & $\mathrm{H} \rightarrow \mathrm{L}+6(+12 \%)$ \\
\hline & 337.7 & 3.67 & 0.9205 & $\begin{array}{l}\mathrm{H}-1 \rightarrow \mathrm{L}+5(+39 \%) \\
\mathrm{H}-2 \rightarrow \mathrm{L}+21(15 \%),\end{array}$ & $\begin{array}{l}\mathrm{H} \rightarrow \mathrm{L}+21(17 \%) \\
\mathrm{H}-1 \rightarrow \mathrm{L}+6(+7 \%)\end{array}$ \\
\hline
\end{tabular}




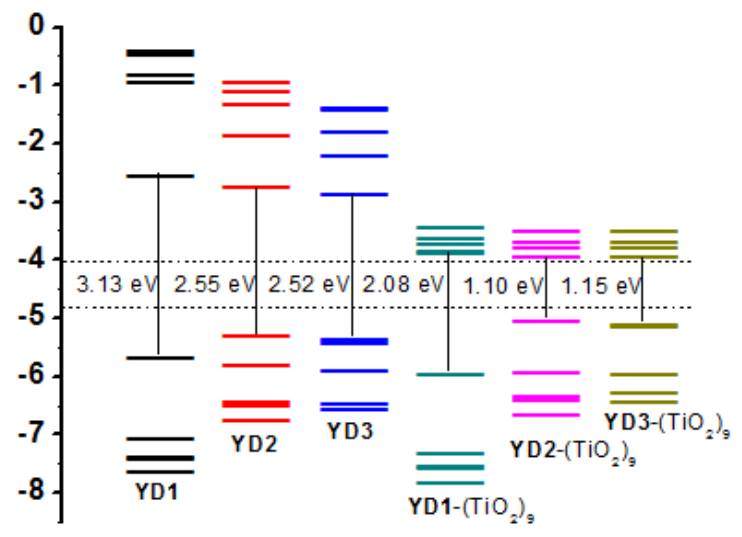

Fig.S1 Molecular orbital energy diagram of YD1-3 before and after binding to $\left(\mathrm{TiO}_{2}\right)_{9}$ clusters by B3LYP hybrid functional alone with 6-31G*for $\mathrm{C}, \mathrm{H}, \mathrm{O}, \mathrm{N}, \mathrm{S}$ atoms, effective core potential (ECP) LANL2DZ and its accompanying basis set for Ti atom

$\mathrm{YD} 1-\left(\mathrm{TiO}_{2}\right)_{38}$
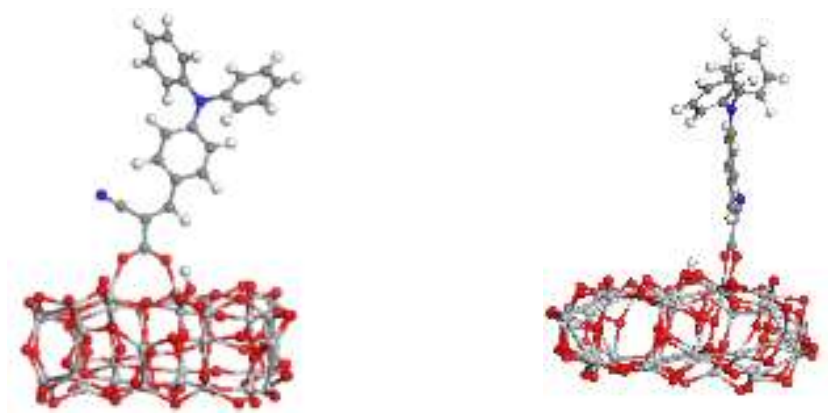

$\mathrm{YD} 2-\left(\mathrm{TiO}_{2}\right)_{38}$
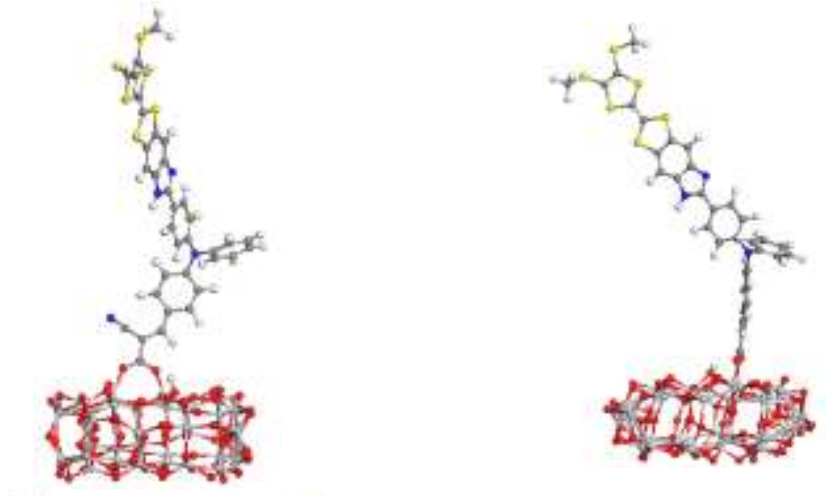

$\mathrm{YD} 3-\left(\mathrm{TiO}_{2}\right)_{38}$
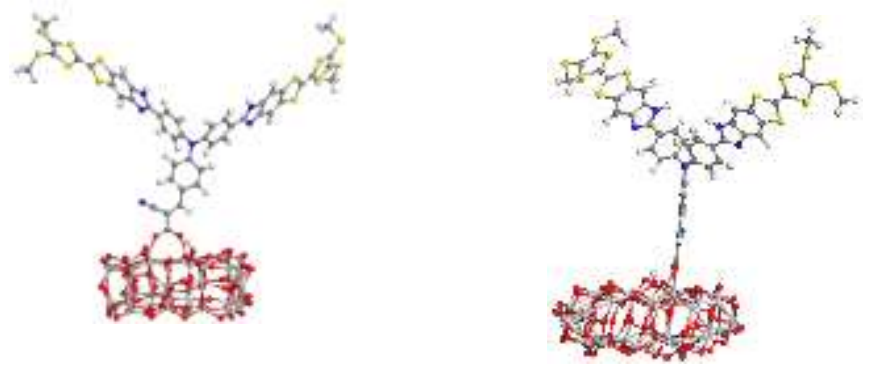

Fig.S2 Optimized structures of YD1, YD2 and YD3 adsorbed on $\left(\mathrm{TiO}_{2}\right)_{38}(101)$ surface by $\mathrm{DMol}^{3}$ calculation 